\title{
Maintaining the Balance: Creative Practices in University-School Partnerships for Teacher Education
}

\author{
David Palmer \\ School of Education, University of Newcastle, Newcastle, New South Wales, Australia \\ Email: David.Palmer@newcastle.edu.au
}

Received 22 April 2015; accepted 9 August 2015; published 12 August 2015

Copyright (C) 2015 by author and Scientific Research Publishing Inc. This work is licensed under the Creative Commons Attribution International License (CC BY). http://creativecommons.org/licenses/by/4.0/ (c) (i) Open Access

\begin{abstract}
The professional placement is a central component of any teacher education program. In recent years, as teachers face a variety of new challenges that make substantial claims upon their time it is more than ever important that university-school partnerships include built-in components that will explicitly benefit teacher/mentors and the students in their schools. By including a combination of literature review and reports from experienced and innovative field operators, this paper has summarized a range of creative strategies that will enhance university partnerships with schools. For teacher education, it is vital that such partnerships continue to flourish, and it is hoped that this paper will contribute to that process.
\end{abstract}

\section{Keywords}

\section{Teacher Education, Partnerships, Mentors}

\section{Introduction}

For many years, teacher education researchers have been interested in improving university-school partnerships and investigating the ways in which it is possible to optimise experiences for preservice teachers and the teacher/mentors. Much of this research has focused on the quality preservice teacher professional development that is afforded by these alliances. Recent researches have consistently shown that when partners have a shared set of core beliefs and a commitment to enact these through key social practices then the partnership can address the gap between theory and practice and can enhance preservice teacher engagement and learning (Allen, Howells, \& Radford, 2013; Miller, 2015).

However, a true university-school partnership should offer advantages for the school-based partners as well as 
the preservice teachers. In recent years, university educators have become more and more aware of the many challenges faced by classroom teachers as high stakes testing and associated accountability pressures take up more and more discretionary time (Bier et al., 2012). Other challenges arise when teachers are expected to take on increased responsibilities, or operate with little administrative support, and inadequate training relative to student needs (Nugent \& Faucette, 2013). Thus, collaborative partnerships must be designed to produce benefits for both university and school based educators and their students, and these must be seen to be of value to both partners.

The purpose of the present study is to report on a range of models that are currently designed to not only provide positive experiences for preservice teachers, but also to offer specific advantages to the teacher/mentors and their schools. It is hoped that reporting of these relatively innovative practices will provide food for thought for university teacher educators and partner schools.

\section{Literature Review}

It should be emphasized that traditional mentoring of preservice teachers does have some advantages for school partners. When teachers act as mentors for preservice teachers and receive appropriate support from university faculty they can feel renewed and this reignites their commitments to best practices and professional advancement: Nugent and Faucette (2013) for example, found that some teachers deeply regret losing interns when the program ends. There are also benefits to schools as such partnerships can provide a supply of recent graduated teachers into schools with which they are familiar as they have completed professional activities at that site (Allen, Howells, \& Radford, 2013).

One model that has been widely approved occurs when preservice teachers collaboratively plan and deliver a series of lessons in a particular content area, and these are observed by the partnership teacher. This can have mutual benefits for both parties when the subject area is one in which the partnership teacher is in need of professional development. Under these conditions the inservice teachers can model new and innovative techniques that they have been recently taught at university. Science is a particularly good example of this type of experience as many elementary teachers lack interest and confidence in teaching science. Kenny (2012) for example, reported that principals value this type of program as an opportunity to improve the quality of science taught in the school and as a form of professional development that addressed some of the common barriers to teaching science in elementary schools, including lack of teacher confidence and lack of time for preparation and gathering of resources.

Professional development schools (PDS) partnerships have historically played a central role in preservice teacher education. In the past however, some educators have questioned their effectiveness and have called for proof that professional development schools make a difference. Recently, Nath, Guadarrama, and Ramsy (2011) reported a number of studies showing that becoming a partnership school can enrich the education of its stakeholders. It has become clear that such schools produce educators who are highly self-reflective and who are able to implement a variety of strategies. These can be particularly effective when preservice teachers have experiences in a range of different types of schools, so they develop the confidence to consider teaching in more challenging settings. However, they are not without their challenges. For example, the National Council for the Accreditation of Teacher Education (NCATE) has developed a set of standards for professional development schools, and one challenge for these partnerships will be for all partners to agree on the benefits and interpretation of these standards (Colwell et al., 2014).

Often seen as essential to the development of an effective alliance are professional learning communities (PLCs) in which university staff can work with teachers to create a shared vision for improving student learning and accepting accountability for making this happen within their school sites. For example, Bissaker (2014) reported findings from one school in which teachers and academics worked as professional partners to develop an interdisciplinary curriculum. The report emphasised the importance of valuing rather than dismissing the dissonance that occurred between these groups. Similarly, Eargle (2013) reported that his school-university partnership facilitated teachers to experiment with new strategies, and stimulated reflective practices.

A number of authors have also reported the continuing use of action research projects in which a university partner can support teachers and education students to explore solutions to issues associated with their teaching practice. These classroom-based teacher research projects can provide benefits for stakeholders when they specifically attend to quality indicators that grow out of the inservice teachers' needs in specific areas; for example, 
to work with and understand test data in order to support student achievement (Nath, Guadarrama, \& Ramsy, 2011). Reynolds, McCormack, and Ferguson-Patrick (2006) reported however, that one potential problem with this model was that the university partner often came into the relationship as a stranger and had to build a professional relationship with school-based staff in a short period of time.

Not all programs however, involve the direct participation of preservice teachers. An innovative approach to develop positive relationships with schools is the after school program in which school students are paired with university-based mentors to carry out specialist studies. Monk et al. (2014) for example reported an informal, place-based environmental education initiative which fostered this type of relationship between scientists, educators and high school students. The high school students and their mentors carried out science-based environmental research projects that were presented one year later at a science fair. The students enjoyed forming a bond with their mentors, increased their environmental awareness and improved their understanding of the scientific method.

It is also important to emphasize the advantages of recognising possible partnerships outside of the traditional university-school format. Brophy (2011) reported that some universities had developed positive associations with education associations, community organisations, individuals and businesses. For preservice teachers, participation in these types of partnerships provided real world experiences and contact with professionals. However, they also provided professional development opportunities and opportunities for collegiality for university and school-based teachers. One challenge for these partnerships is that they can involve a serious commitment of time from the individuals that initially develop them, as well as an ongoing ability to schedule and maintain effective communication.

\section{The Present Study: Methods}

The aim of this study was to provide a detailed analysis of a range of partnership techniques that can offer advantages not only for the preservice teachers, but also for the teacher mentors. The emphasis was on techniques that have practical application because they have been tried and tested in the field and found to be workable over an extended time period.

The study used a cross-section design and data gathering was by focus group interview and individual interview. Interview was chosen because it would allow in-depth analysis of the details of the partnerships, and the use of probing questions and interviewer paraphrasing would ensure clarity.

The participants in the focus group interview were five, highly innovative teacher educators who were involved in a variety of creative university-school partnerships. All participants came from the same city. This was a large city located in the eastern USA, and a wide range of demographic and socio-economic groups were represented within. All participants were experienced teacher educators who had been responsible for coordinating their own university-school partnership programs.

In the focus group interview, each educator was asked to describe: 1) the aim and rationale for the partnership, 2) the nature of the partnership and details of its operation, 3) the benefits to preservice teachers and teacher mentors, and 4) their analysis and general comments about the program. Comments and discussion from the other participants was encouraged, as this was seen as adding to the potential for generalisability of each program.

After the focus group interview the researcher reviewed the data to identify areas in which further information was needed. One program was identified as such, and an individual interview was carried out with this participant one week later. This interview was intended to provide further insight into the practices involved.

To ensure accuracy and validity, each participant was asked to review a draft of the manuscript and to suggest changes if necessary.

\section{Analyses and Discussion}

The results provided in this section will be presented as an objective reporting of the participants' views. The emphasis will be on specific issues that the participants agreed were central to the success of their partnerships and of specific benefit to teacher mentors.

The participants in this study emphasized that many teachers and schools are happy to provide mentoring for preservice teachers simply because it is in the best interests of the profession as a whole, and they often ask for no incentive other than the opportunity to give back to the profession that has provided them with a rewarding 
career. However, it is important to recognise that mentoring of preservice teachers does itself require considerable expenditure of energy by the teacher/mentor, and one concern expressed by teachers is that they don't have enough time to spend with weaker preservice teachers who might require greater assistance. Of course it is difficult to predict beforehand which preservice teachers might perform poorly, but once they have been identified, it is preferable to place them with specially selected teachers who have been identified as being able to provide strong support and who have been kept free from other supervisions so they are available for this purpose when they are needed. These teachers should not be asked to do this regularly however, as attempting to mentor two needy preservice teachers in a row can contribute to teacher burnout.

It is also preferable to maintain communication with school partners about professional placement policies and procedures that may potentially create tension. For example, school districts often want preservice teachers to have placements in underperforming schools, because this can allow co-teaching to occur and it is possible to plan instances of individual and small group instruction which will be beneficial to students. However, many university partners would prefer the preservice teachers to work with master teachers first and learn best practices in a relatively supportive context. Their fear is that preservice teachers may lose hope if they are exposed to difficult situations too early in their training. These kinds of tensions must be negotiated throughout the partnership and the importance of arriving at a consensus must be recognized by both parties.

The interviewees also described a variety of creative and innovative strategies that can be used to build successful partnerships that have benefits for the school partners. They emphasized however, that there must be an impetus from the school to be involved in the partnership. Preferably, these schools will have dynamic leaders and teachers who are interested in partnerships, as these are the situations in which partnerships have the most chance of success. It is also preferable to identify schools that have a relatively low rate of teacher attrition, as a high turnover in staff makes it very difficult to maintain long-term initiatives. However, if suitable partners are identified first and initial procedures for working together are put in place then it is possible to develop highly creative and successful partnerships.

One form of partnership involves a relatively traditional combination of preservice teacher placements combined with action research, but also includes professional development training for teacher/mentors at school and at the university. The action research component involves generating data about the schools on topics and issues that the schools want to know about. This can involve weekly study groups for teachers to discuss how to implement ideas in the classroom then trial them and report the outcome. These usually involve the participation of a university professor, but it is important to match the skills and interests of the university professor are matched to the type of projects which the teachers wish to pursue. Thus, what the professor brings to the relationship is important.

Alternatively, the action research project can be carried out by the preservice teachers. When this occurs, it is important that the teacher/mentors are asked to collaborate to develop the questions to be investigated, as this ensures that the project focuses on issues that are of interest to the school personnel. Students can be heavily involved at this stage as they can work with a teacher and university professor to provide ethnographic analyses and to pose questions that would be interesting to answer. It is important to emphasize that these projects do not necessarily have to be completed in a one-semester time frame while the intern is at the school. In fact, projects can be extended by having a new set of students following up the same projects the following year, or by having a group of interns working collaboratively on different aspects of the same project, including the literature reviews and methodology and recommendations arising from the literature reviews. Under these conditions the intern would be assessed only on the component in which he or she was directly involved. One student for example might be asked to develop three different options for methodologies that could be used, and this student would be assessed on this component only. In this type of project, it is essential that students are given careful guidelines about what is expected, and that the instructions given to students are checked carefully for ambiguity. Importantly, this type of project can provide ongoing professional development for the teacher/mentors as they monitor the progress of the project and provide feedback to the preservice teachers.

Two-day seminars held at the university are an important component of the professional development training component. Currently, much of the professional development that teachers do can be categorized as compliance professional development, in which they are instructed how to do the mandated paperwork for the external education bodies. The teacher's perceived needs for professional development are often different to these however, so when the university provides inservice training on other issues such as teaching reading and writing, or how to integrate technology into different disciplines, it can be valued by the teachers. Experienced teachers often 
differ to new teachers in the kinds of professional development that they might find appealing, and this should also be considered. Of course universities can also provide leadership on the mandated professional development as well, and in these cases the regional curriculum specialist should be included in the partnership. In all cases however, it is vital the school has trust in the relationship.

It is not always necessary to develop new initiatives in order to provide mutually beneficial experiences for both preservice teachers and schools. In some cases, preservice teachers have been placed in after-school programs that are already running. These outreach programs usually involve on-site participation in after-school tutoring. Preservice teachers can participate for 2 - 3 hours per week. Although it is not part of the normal school routine, the experience benefits the school students by providing individual tutoring. The preservice teachers can be required to keep weekly journals, discuss dilemmas and consult with each other. Their final project can evolve over the course of the semester, and may result for example, in a group project that recommends how to make the initiative more productive. Special needs children can particularly benefit from these types of individual experiences with preservice teachers and these do not always have to involve formal tutoring - simply sitting down with a student in the playground and having lunch together on a regular basis can be a powerful experience both for that student and the preservice teacher. An alternative that is feasible when appropriate funding is available is to support underprivileged youth empowerment by busing students from their neighbourhoods to the university to provide mentoring in specialist skills such as preparing applications for college, managing finances and managing personal health and nutrition, and cultural identity. These types of programs can be most effective when they also include participation by other bodies such as social work specialists.

Another function of the university professor is to act as a source of contacts that the school might use. For example, a school might need a specialised person as a keynote speaker for a special event or a person who can provide special advice, and in these cases the university professor can use his her contacts to provide a suitable suggestion. In this way, the professor becomes a resource person and a go-between.

Of course, mentoring preservice teachers can and should be counted as an important component of teacher professional evaluations. However, there are other ways in which teacher/mentors can build their professional profiles. The university can, for example provide course credit for teachers who have supervised a certain number of students. This would for example, count towards credit allocated by the university in a coursework higher degree. Alternatively, university staff can offer to meet monthly with a new teacher to discuss, mentor and observe them. University staff are in an ideal position to assist new teachers in this way, as they are not part of the school so teachers can honestly discuss sensitive issues without fear of repercussions.

\section{Conclusion}

The professional placement is a central component of any teacher education program. In recent years, as teachers face a variety of new challenges that make substantial claims upon their time it is more than ever important that university-school partnerships include built-in components that will explicitly benefit teacher/mentors and the students in their schools. It is often the details of how the partnerships are set up and managed that play a large role in determining the degree of success or failure. By including a combination of literature review and reports from experienced and innovative field operators, this paper has summarized a range of creative strategies that will enhance university partnerships with schools. For teacher education, it is vital that such partnerships continue to flourish, and it is hoped that this paper will contribute to that process.

\section{Acknowledgements}

Many thanks to Ann Renninger, Cheryl Jones-Walker, Elaine Allard, Edwin Mayorga, Lisa Smulyan, and Cathy Dunn for their advice in the preparation of this manuscript.

\section{References}

Allen, J. M., Howells, K., \& Radford, R. (2013). A "Partnership in Teaching Excellence”: Ways in Which One School-University Partnership Has Fostered Teacher Development. Asia-Pacific Journal of Teacher Education, 41, 99-110. http://dx.doi.org/10.1080/1359866X.2012.753988

Brophy, T. S. (2011). School-University Partnerships in Music Education: A Status Report. Arts Education Policy Review, 112, 149-153. http://dx.doi.org/10.1080/10632913.2011.566092 
Colwell, C., MacIsaac, D., Tichenor, M., Heins, B., \& Piechura, K. (2014). District and University Perspectives on Sustaining Professional Development Schools: Do the NCATE Standards Matter? Professional Educator, 38, 17-26.

Eargle, J. C. (2013). “I’m Not a Bystander”: Developing Teacher Leadership in a Rural School-University Collaboration. Rural Educator, 35, 23-33.

Kenny, J. D. (2012). University-School Partnerships: Pre-Service and In-Service Teachers Working Together to Teach Primary Science. Australian Journal of Teacher Education, 37, 57-82. http://dx.doi.org/10.14221/ajte.2012v37n3.1

Miller, L. (2015). School-University Partnerships and Teacher Leadership: Doing It Right. Educational Forum, 79, $24-29$. http://dx.doi.org/10.1080/00131725.2015.972810

Monk, M. H., Baustian, M. M., Saari, C. R., Welsh, S., D’Elia, C. F., Powers, J. E., Gaston, S., \& Francis, P. (2014). Environmentors: Mentoring At-Risk High School Students through University Partnerships. International Journal of Environmental and Science Education, 9, 385-397.

Nath, J. L., Guadarrama, I. N., \& Ramsy, J. (2011). Investigating University-School Partnerships. IAP.

Nugent, P., \& Faucette, N. (2013). Empowering Innovations: Adding Value to University-School Partnerships. College Student Journal, 47, 567-578.

Reynolds, R., McCormack, A., \& Ferguson-Patrick, K. (2006). University/School Partnerships: Journeys of Three Academic Partners. Annual Conference of the Australian Association for Research in Education, Parramatta, 27 November 266, $1-11$. 